\title{
FROM CONFLICT TO ASSIMILATION: STRATEGIES OF MUSLIM IMMIGRANTS IN PAPUA SPECIAL AUTONOMY ERA
}

\author{
Faisal $^{1}$, Abdul Munir Mulkhan², Achmad Nurmandi ${ }^{3}$, Hasse Jubba ${ }^{3}$ \\ ${ }^{1}$ Islamic Politics, Universitas Muhammadiyah Yogyakarta-Institut Agama Islam Negeri Fattahul Muluk Jayapura \\ Jalan Brawijaya, Tamantirto, Bantul, Daerah Istimewa Yogyakarta, Indonesia. \\ ${ }^{2}$ Universitas Muhammadiyah Surakarta, Jalan A. Yani, Mendungan, Pabelan, Kec. Kartasura, Kabupaten Sukoharjo, \\ Jawa Tengah, Indonesia \\ ${ }^{3}$ Islamic Politics, Universitas Muhammadiyah Yogyakarta, Jalan Brawijaya, Tamantirto, Bantul, Daerah Istimewa \\ Yogyakarta, Indonesia \\ E-mail: faisalsaleh72@yahoo.co.id
}

\begin{abstract}
This paper aimed to explain the forms of Muslim immigrant strategies in Papua in the era of special autonomy. After the implementation of it in Papua, increased tension occurred especially in economic and political fields. Data for this research were obtained through the method of observation, interviews, and literature studies. Observations focused on the economic practices of Muslim migrants in places such as the market in Jayapura, Papua. Interviews were conducted with many parties, both Muslim migrants and local Papuans to obtain information on many things including their responses to the presence of Muslim migrants. Besides, data was also obtained through the documentation of some literature related to the topic of this paper. The data gathered are then analyzed through the steps of qualitative analysis, namely data reduction, data presentation, concluding/verification. This paper confirms that Muslim migrants made various efforts to deal with various obstacles in the era of Special Autonomy in Papua in three ways. First, Muslim migrants strengthen their economy capacity, especially in the informal sector. Secondly, the political sector is not the main objective of the existence of Muslim migrants in Papua. Third, Muslim migrants are not exclusive, especially in establishing communication with indigenous people.
\end{abstract}

Keywords:

Special Autonomy; Conflict; Assimilation; Muslim Immigrants; Papua.

\begin{abstract}
Abstrak
Tulisan ini bertujuan untuk menjelaskan bentuk-bentuk strategi Pendatang muslim di Papua di era otonomi khusus. Pasca pemberlakuan otonomi khusus di Papua, warga pendatang merasakan semakin tingginya tensi atau persaingan di lapangan ekonomi dan politik. Data diperoleh melalui metode observasi, wawancara, dan studi literatur. Observasi difokuskan pada praktik ekonomi pendatang Muslim di beberapa tempat seperti pasar di Jayapura Papua. Wawancara dilakukan kepada sejumlah pihak, baik warga muslim pendatang maupun penduduk lokal Papua untuk memperoleh informasi mengenai banyak hal termasuk respons mereka terhadap keberadaan pendatang Muslim. Di samping itu, data juga diperoleh melalui dokumentasi sejumlah literatur yang terkait dengan topik tulisan ini. Data yang diperoleh kemudian dianalisis melalui langkah-langkah analisis kualitatif, yakni reduksi data, penyajian data, penarikan kesimpulan/verifikasi. Tulisan ini menegaskan bahwa pendatang Muslim melakukan berbagai upaya menghadapi berbagai kendala di era Otonomi Khusus Papua melalui tiga cara. Pertama, pendatang muslim memperkuat ekonomi, khususnya sector informal. Kedua, sector politik tidak dijadikan tujuan pokok keberadaan pendatang Muslim. Ketiga, pendatang muslim tidak bersikap eksklusif khususnya dalam membangun komunikasi dengan penduduk asli.
\end{abstract}

Kata Kunci:

Otonomi Khusus; Konflik; Asimilasi; Imigran Muslim; Papua.

DOI: $10.15575 /$ jw.v4i1.5190

Received: January 17, 2019; Accepted: March 20, 2019; Published: July 29, 2019 
Faisal, Abdul Munir Mulkhan, Achmad Nurmandi, Hasse Jubba

\section{A. INTRODUCTION}

In his study of Turkish Muslim immigrants in Germany, Pecoud ${ }^{1}$ and Gusnelly ${ }^{2}$ argued, that the process of integration of Turkish immigrants in German society was so easily carried out through political and economic activities. In other words, business or entrepreneurship exists as one of the factors that help breaking down traditional boundaries, which often have become a stereotype between migrants and the host country. Factually, this proposition is motivated by changes, both Germans and migrants. Among Germans, there is a tendency for increasing goods consumption that was previously identified to migrants. ${ }^{3}$ Some of the items that were originally "ethnic" have now become "German", for example, clothing. In contrast, among Turkish immigrants, the second and third generations have also adopted goods and lifestyles that were previously only considered Germanic, such as technological products. The process of integration through political and economic channels is possible, in addition to the role of

1Antoine Pecoud, Weltoffenheit Schafftjobs: Turkish Entrepreneurship and Multiculturalism in Berlin (Oxford, UK: University of Oxford, 2000).

2Gusnelly, "Migrasi, Kewarganegaraan, Dan Partisipasi Ipendatang: Studi Kasus Pendatang Turki Di Belanda," Jurnal Kajian Wilayah 1, no. 1 (2010): 59-78.

${ }^{3}$ Zinggara Hidayat, "Dampak Teknologi Digital Terhadap Perubahan Konsumsi Media Masyarakat," KOMUNIKOLOGI: Jurnal Ilmiah Ilmu Komunikasi 13, no. 2 (2016), 60.

${ }^{4}$ Chris Allen, Islamophobia (England: Ashgate Publishing Limited, 2010). See also Chris Allen, "Contemporary Islamophobia Before 9/11: A Brief History in Islamophobia and Anti-Muslim Hatred: Cause \& Remedie," Arches Quarterly 4, no. 7 (2010): 14-22. See Runnymede Trust, Islamophobia: A Challenge for Us All (London: Runnymede Trust, 1997).

${ }^{5}$ Rahat Raja, "Muslims in Europe A Shared Citizenship Transcending the Imposition of Cultural Homogeneity," Policy Perspectives, 2012, 109-41. See also K Yu Eidemiller et al., "Social and Islamic Diffusion in the Nordic Countries with the Example of Sweden by Year 2050," in IOP Conference Series: Earth and Environmental Science, vol. 302 (IOP Publishing, 2019), 12071. See also Lucas G Drouhot and Victor Nee,
From Conflict to Assimilation: Strategies of Muslim Immigrants in Papua Special Autonomy Era

government, the strong network that is built-in building and developing business is one of the keys to Turkish success.

The experience of Turkish Muslim migrants proves that integration between local communities and migrants allows it to work easily in the political economy. The success of Turkish Muslim immigrants was not followed by Muslim immigrants in several European countries. To a certain extent, local people still feel concern about Muslim migrants. This deep concern then gave rise to 'Islamophobia', ${ }^{4}$ in some European countries. The case in New Zealand, some time ago, proved that there are still some people who are worried about the presence of Muslim migrants. This is made worse by the condition that some of the Muslim migrants cannot assimilate into European society. ${ }^{5}$

In the Indonesian context, the tension between the migrants and the local population is quite high. Especially since the government implemented the transmigration program. ${ }^{6}$

"Assimilation and the Second Generation in Europe and America: Blending and Segregating Social Dynamics between Immigrants and Natives," Annual Review of Sociology 45 (2019).

6 The transmigration program in Indonesia has long been known and carried out since the days of the Dutch Colonial government. At the beginning of the 20th century, a transmigration program was carried out, then known as the Colonization or opening of a new colony. The initial idea of the colonization program was to reduce the pressure of the population in Java and to build a colony by bringing people from Java to other islands. Colonization has been very important since the introduction of ethical politics in Indonesia. The first place used as a residential area on the southern island of Sumatra, precisely in Lampung in 1905. See Bayu Setiawan, "Program Transmigrasi: Upaya Mengatasi Permasalahan Kependudukan Dan Meningkatkan Kesejahteraan Masyarakat," in Pertumbuhan Penduduk Dan Kesejahteraan, ed. Mita Noveria (Jakarta: LIPI Pres, 2011), 179. The period of transmigration during the last century can be divided into three periods, namely (1) the era of the Dutch colonial government, 1905-1941, 2) Japanese occupation period, 1942-1945, and (3) period after Indonesian independence, 1945-2005. The description in this article divides the era of Dutch colonial rule into the stage of colonization trials between 1905-1911, the Lampongsche Volksbank period in the 
Faisal, Abdul Munir Mulkhan, Achmad Nurmandi, Hasse Jubba
From Conflict to Assimilation: Strategies of Muslim Immigrants in Papua Special Autonomy Era
Although this program is an official government program, it does not reduce the tension. Large-scale movement, both official and informal, of some residents to various parts of the country, also left many tensions and even intense conflicts in several regions. The conflict is usually motivated by the struggle for political-economic space, the struggle for identity. In this condition, nativism strengthens. Concerns about the threat of domination by migrants also strengthened. In several regions, migrant communities are feared that they will stabilize all the economic, political, and other spaces that local communities should have. The tension ultimately led to this conflict was exacerbated by the weakening of the desire of migrants to assimilate with the local population. Cases like this can be found in several places like in West Kalimantan where groups of migrants are more advanced because of their hard work.

In Papua, as a whole, is a region with a fairly large number of migrant communities, as is the case with some regions outside Java. Almost all ethnicities in this country come to Papua, a country with considerable natural resource potential and quite a large business potential. ${ }^{7}$ They come with a variety of motives, which generally come from economic interests. Since the New Order era, a wave of residents to Papua progress. Even today, the influx of people entering quickly goes hand in hand with improved transportation routes. The migrants no longer go by sea, but also by air. This condition has an impact on changes in demographics in Papua, especially in Jayapura. Indigenous people have got a 'mix' of migrants.
The presence of migrants' changes from time to time. In fact, in 2000-2001 there was an open conflict in Jayapura marked by an outflow of migrants. They returned to their respective regions because they were rejected by the natives. This was later responded through granting autonomy to Papua through Law Number 21 of 2001 concerning Special Autonomy for Papua. The implementation of special autonomy for Papua is a political economy strategy to re-strengthen the identity of Papua, even further reaffirming the dominance of local Papuan communities over their land, economic space, and political power. ${ }^{8}$ It was realized, this special autonomy became a 'threat' for migrants who earn a fortune and power in Papua. In this condition, migrants, who are mostly Muslim, must redefine their identity, and even try to find a strategy to survive in the economic and political struggle for power in Papua after special autonomy.

This paper is an analysis of the surviving Muslim migrants' strategy in Papua after the implementation of special autonomy. This survival strategy is carried out within the framework of 'negotiations' with Papuan residents in economic and political affairs. So that it is expected to be able to minimize potential conflicts in the future. The strategy of surviving Muslim migrants, in addition to reaffirming their Muslim identity and ethnicity, at the same time made assimilation efforts with local Papuans.

This study employs a qualitative method. Fieldwork was conducted in Jayapura using observation and in-depth interview among

7 See, Badan Pusat Statistik Provinsi Papua, Produk Domestik Regional Bruto Provinsi Papua Tahun 2015 (Jayapura: Badan Pusat Statistik Provinsi Papua, 2015). See also Muhammad Fajar, "Identifikasi Sektor Potensial Provinsi Papua" (Bandung, 2017).

8I Ngurah Suryawan, "Komin Tipu Komin: Elit Lokal Dalam Dinamika Otonomi Khusus Dan Pemekaran Daerah Di Papua," Jurnal Ilmu Sosial Dan Ilmu Politik 15, no. 2 (2011): 140-53.
Cahaya, 1985), 161. See also Nugraha Setiawan,

Transmigrasi Di Indonesia: Sejarah Dan Perkembangannya (Yogyakarta: Program Studi Kependudukan, Program Pascasarjana UGM, 1994), 5. period 1911-1929, and the era of world economic depression between 1930-1941. Whereas after the era of order government, the new order government, and the reformation period. Look, Sri Ana Handayani, Transmigrasi Di Indonesia Dalam Perspektif Sejarah (Jember: Universitas Jember, 1994). See also I. B Mantra, Pengantar Studi Demografi (Yogyakarta: Nur 
Faisal, Abdul Munir Mulkhan, Achmad Nurmandi, Hasse Jubba

Muslim migrants and local Papuan communities. The data gathered are analyzed through the process of data reductions, data presentations, concluding/verification. ${ }^{9}$

\section{B. RESULT AND DISCUSSION}

\section{Muslim Immigrants in Papua}

The presence of people coming from outside Papua is inseparable from the position of Papua as a strategic region as stated by Daud Yoesoef as "The Heart of Indonesia" due to geopolitical, geomorphological and geoeconomic and geo-theological reasons. ${ }^{10}$ Geopolitically, Papua's position both geographically and geo-strategically is in the "World Cross Position" between four continents and two oceans which makes this region at the center of the world's trajectory. Legendary General Douglas MacArthur could win World War II in the Asia Pacific after choosing Sentani, Jayapura Regency as the base of control of the war strategy at that time. Likewise, President Soekarno, with his intelligence was able to see the importance of Papua for the future of Indonesia. Geomorphologically, the island of Papua is the second-largest island in the world after the island of Greenland, has vast forests as the second contributor of oxygen after the Amazon forest, and morphologically is very varied, ranging from lowland areas to snowy towering mountains. While geo-economically, Papua has extraordinary natural resources and human resources stretching from the stone age to the modern era. Subsequently, since a long time ago many people have in turn come as travelers and merchants and brought missionary missionaries and Islamic missionary missions in the hope that after Papua was saved, it would benefit Papua and other nations.

\footnotetext{
${ }^{9}$ Milles and Huberman, Analisis Data Kualitatif (Jakarta: Universitas Indonesia Press, 1992), 16.

${ }^{10} \mathrm{John}$ Manangsang Wally, Dunia Dalam Genggaman Papua Sebuah Fenomena Geopolitik Global (Jayapura: Yayasan Gratia Papua Jayapura, 2018), 16-

${ }^{11}$ Irwan Abdullah, Konstruksi Dan Reproduksi Kebudayaan. (Yogyakarta: Pustaka Pelajar, 2006).
} 17.
From Conflict to Assimilation: Strategies of Muslim Immigrants in Papua Special Autonomy Era
There are three concepts of Cohen quoted by Irwan Abdullah about a person migrating. The concepts are "home", "place", and "citizenship". The concept of home as a symbol of the condition of feeling that always feels homesick and remembered by the house in the hometown left behind that feels far in the land of people. Likewise, the place is considered as a matter to show the social and economic status of a person. It is about the quality of their life in their destination of migration. While citizenship is related to the political aspect of their legal status in the area of destination. ${ }^{11}$ These three things also illustrate the face of Muslim migrants who come to Papua. Although what often appears on the surface is the second concept, namely for trade or economy, and political and social factors.

The migration process then took place more massively after the implementation of the transmigration project and the sending of teachers, and civil servants, and others assigned to accelerate the development of Papua. This is in line with the approach of a new order economic development strategy by opening up new areas in Papua. The transmigration program began in 1964, since the reign of the New Order. They came from Java, Sulawesi, Maluku, Sumatra, Kalimantan. ${ }^{12}$ The first transmigration project pilot site was 36 families out of 94 people and placed in 2 (two) transmigration settlement units, namely UPT Dosay, Jayapura, 9 families out of 22 people and UPT Kumbe in Merauke, 27 families / 72 people, then in other areas in Papua such as in Biak, Nabire, Sorong, and Manokwari.

In addition those who came with the transmigration program, migrants currently migrate voluntarily such as the BugisMakassar-Buton people, and others. Garnaut

\footnotetext{
${ }^{12}$ Toni Victor M. Wanggai, Rekonstruksi Sejarah Umat Islam Di Tanah Papua (Jakarta: Badan Litbang dan Diklat Departemen Agama, 2009), 143. See also Rudi Hartono Ismail and Rianik Thomas, "Building the Civilization in the Perspectives of Islam in Jayawijaya Regency, Papua, Indonesia: The Development of Islam in the Aspect of Human Resources," HONAI 1, no. 1 (2018): 61-72.
} 
Faisal, Abdul Munir Mulkhan, Achmad Nurmandi, Hasse Jubba

and Manning in Akhmad research ${ }^{13}$, explained that the arrival of Sulawesi people, especially Bugis-Makassar people, in Papua after the end of colonial rule in 1963 was driven by the condition of the number of foreign companies that needed other people from outside Papua. Even before that, the history of Bugis-Makassar traces had existed since the 1700s when BugisMakassar sailors sailed "Marege" to search for sea cucumbers to northern Australia. The word "Marege" is usually used by the BugisMakassarese to refer to Papuans. On their way they dropped to Papua, some later chose to settle in Papua. ${ }^{14}$

In the Kompas Expedition Report to Papua, it was stated that the Bugis-Makassar people had filled the traditional market stalls on the island since the 1970s. ${ }^{15}$ In Jayapura, Many of them traded at the Old Sentani Market, Prague New Market, Sentani, Ampera Market, Hamadi Central Market, Abepura Market, and Yotefa Market. In addition to Jayapura, BugisMakassar traders were also often found in Timika, Sorong, and Merauke. They opened small businesses from grocery trading, forest entrepreneurs, to the transportation business. They dared to enter the forest, climb mountains and open the wild into productive land. In strengthening their presence in the overseas ethnic diversity and their mingling with others, they became solid as a fellow on behalf of migrants in the Jayapura Papua region by forming fraternal ties that were fostered in the community of associations that they called the Nusantara Circle of Friends. This regional organization then interacted with various

\footnotetext{
${ }^{13}$ Pujo Semedi Akhmad, “Amber Dan Komin: Studi Perubahan Ekonomi Di Papua," Sosiohumanika 16B, no. 2 (2003): 229--245.

${ }^{14}$ Ismail Suardi Wekke, "Migrasi Bugis Dan Madura Di Selatan Papua Barat: Perjumpaan Etnis Dan Agama Di Minoritas Muslim," Jurnal Intelektualita: Keislaman, Sosial Dan Sains 6, no. 2 (2017): 163--180.

15 Fandri Yuniarti, ed., Ekspedisi Tanah Papua: Laporan Jurnalistik Kompas Terasing Di Pulau Sendiri (Jakarta: Kompas, 2008).

${ }^{16}$ Saprillah, "Migrasi Kaum Muslim Ke Sorong Papua Barat," Al-Qalam 17, no. 2 (2011): 251-61. See also Wekke, "Migrasi Bugis Dan Madura Di Selatan
}

parties including indigenous Papuans. This relationship was then capitalized as migrant social capital to strengthen their positions, including in occupying political positions that could be filled by them such as the position of deputy regent and deputy mayor, and positions in government. The migrants were also aware of the consequences of special autonomy for native Papuans that have been affirmed by the law.

\section{Strategies of Muslim Immigrants in Papua Post Special Autonomy}

The social and economic changes that have taken place in Papua and West Papua are heavily influenced by migration. ${ }^{16}$ Migration has colored many changes and dynamics in many aspects of life in Papua. Migration can be voluntary (trading and others), but also because of military and staffing duties, or even religious reason. ${ }^{17}$

The enactment of the 2001 Special Autonomy Law for the Province of Papua has very broad implications in the lives of the people, especially Muslim migrants. Influence does not only occur in the economic field but also in the political, social and religious fields. This law also triggers a reaction in the Papuan community, whether it supports, criticizes or resigns to circumstances on the one hand, but can also bring a movement to strengthen themselves so that they can survive even in a state of minimal government support on the other.

This autonomy itself gives privileges to indigenous Papuans and has given birth to

Papua Barat: Perjumpaan Etnis Dan Agama Di Minoritas Muslim." See also Stuart Upton, "The Impact of Migration on the People of Papua, Indonesia: A Historical Demographic Analysis" (Department of History and Philosophy, UNSW, 2009).

${ }^{17}$ Budi Asyhari-Afwan, Mutiara Terpendam Papua Potensi Kearifan Lokal Untuk Perdamaian Di Tanah Papua (Yogyakarta: CRCS UGM, 2015), 14 
Faisal, Abdul Munir Mulkhan, Achmad Nurmandi, Hasse Jubba

community segmentation. One form of privilege is that the Governor of Papua must come from the Orang Asli (natives). This segmentation even led to the dominance of many important sectors of social life in the Jayapura District which emerged due to responses to various conditions during the autonomy policy was enacted. In response to the dynamics of life in Jayapura Papua, Muslim migrants made various efforts to support their current existence and future sustainability.

Generally, migrants in various places, need survival strategies to maintain their existence in dealing with the dynamics of the local community. Among many migrant choices is to assimilate to the lives of local people, or to form a particular community group. The latter choice often becomes a big problem that results in conflicts with local or indigenous communities. In the case of Papua, the struggle between the migrants and the indigenous community lasted for a long time. This dialectical process then makes these two big entities on earth increasingly find points of meeting, assimilation, and maturity in accepting other parties. The form of meetings that greatly affects their relationships is transactions in markets. More Papuans are buyers, while migrants are sellers. This meeting, for example, was found in Hamadi Market, where the market was dominated by migrants as the main economic actors.

Economically, there is the segmentation of these two community entities. The economic dominance of the formal and informal sectors is controlled by migrants. Papuans are only dominant in the business and trade sectors, such as in transportation services. While in the informal economy, migrants are more prominent in almost all lines. Starting from the trade sector, carpentry/furniture, livestock, home industry, restaurants, tailors, barbershops, up to contractor services and types of service businesses. The spirit of trade and the effort for migrants to develop their economy in the Papuan economy is inseparable from their habits and tenacity they have struggled since the beginning of their stay. This struggle has to lead to success in business, albeit slowly, but
From Conflict to Assimilation: Strategies of Muslim Immigrants in Papua Special Autonomy Era surely continue to advance and contribute to advancing the Papuan economy. This tenacious spirit continues to be maintained and is part of the immigrant life enthusiasm.

Responding to this situation, migrants sought ways to strengthen themselves among them by strengthening primordial ties in every trading business activity. Regional communities such as Java, Madura, Sulawesi, and others are very active in carrying out various social activities. The migrant entrepreneurs in their activities then use labor based on kinship relationships and/or at least the same ethnicity as the business owner. Primordial strong ties directly support the development of the informal economy which has been their "domain".

To strengthen regional-based community ties, various activities are carried out in addition to strengthening social relations, as well as the media creating new collectivities, especially in the economic field. They believed that developing the economic sector will be able to push the pace of change in living standards for the better. This, in turn, could support a high level of regional enthusiasm among migrants in the Jayapura district. One of the migrants, a leader of the Southeast Sulawesi Community, acknowledged the benefits gained from the meetings held so far. He said:

I often hold meetings or training for the people of Buton specifically to improve the quality of human resources, that is in the economic field, ... I also strengthened my local community in their capital development, because if they can develop their business's strength, they can share with other communities. I suppose that. We once made a kind of joint savings, such as an arisan, and form a joint venture group, and in 2013, our funds reached 18 billion here in 
Faisal, Abdul Munir Mulkhan, Achmad Nurmandi, Hasse Jubba

Jayapura, that's what we used to run our business. ${ }^{18}$

This narration indirectly recognizes the importance of meetings based on regional bonds. This also confirms that the group of migrants has a hand in restoring their regional spirit. However, the spirit of regionalism is still wrapped in the ties of newcomer collectivity which also forms a new group model. ${ }^{19}$ The findings of this study reinforce what has been stated by Snodgrass, that strengthening the economy, especially in controlling the informal economy sector, in addition to strengthening relations between ethnic groups, is also significant. ${ }^{20}$ Community ties from various regions are also used by migrants to strengthen their positions (capital) to gain the trust of indigenous Papuans to carry out their business. Migrant values such as honesty, responsibility and hard work are often considered positive so that Papuans entrust them more to manage their assets. In this case, migrants were able to show a high value of trust in the Papuan people. In the case of businesses, Papuans as capital owners sometimes give entrants confidence in migrants to manage and maintain their assets for years not based on a written agreement, but only because of mutual trust between them. An "S" informant, a rental car driver in Sentani, for example, has been trusted to manage a rental business owned by Papuans. He emphasized:

...it's been a while since I was trusted to bring my boss' car, a Papuan. He even mentioned not to give permission if his family intend to borrow the car. ${ }^{21}$

This belief is not solely because of migrants, but because they are seen as able to create theological values, through religious activities such as monthly recitation, which are available to them to be offered to Papuans so that they

18 A, interview by Faisal, Jayapura, on September 30, 2017.

${ }^{19}$ Atiyatul Izzah, "Jaringan Sosial Dan Variasi Pekerjaan Para Migran Di Kota Samarinda," MASYARAKAT, Jurnal Sosiologii 16, no. 2 (2011): 15780.

${ }^{20}$ Donald R Snodgrass, Successful Economic Development in a Multi-Ethnic Society: The Malaysian can be trusted and these efforts can be mutually beneficial. A culture of honesty, hard work, empathy for people and communicative are theological values for Muslims migrants. Economic competition (trade) in the Jayapura district which is relatively small, benefits them. This condition is widely used by migrants while strengthening the dominance of informal economy control. "WH" for example, openly acknowledges that. In a conversation, he revealed that the trust factor is one of the keys to how economic relations (work) are built.

Outside of project work like that, yes ... there are a few things that are sure to swerve, but on average if I see, not all of them can be entrepreneurs, because there should have modal capital which does not necessarily refer to only financial, but also trust, location, land, place of business, and entrepreneur's capital. There are many Muslim entrepreneurs in Papua. Almost all of them are successful even from small to medium level. It means that according to their ability, they will certainly get any jobs available, sometimes they also can create jobs for our people ...22

The ability of migrants to take business opportunities arises as a result of their past experiences. Some of them have failed many times and turned to more profitable types of work. In short, they made these experiences as lessons to develop their business in a better direction. The ability of migrants to read business opportunities has provided an added value in the context of mastery of the economic sector that cannot be done by indigenous Papuans. The business of buying and selling building materials, for example, is involved in responding to the high prices of building materials in Papua. This ability is also

Case (Cambridge: Harvard Institute for International Development, Harvard University, 1995).

${ }^{21} \mathrm{~S}$, interview by Faisal, Sentani, on September 30, 2017.

${ }^{22} \mathrm{WH}$, interview by Faisal, Jayapura, on November 15,2017 . 
Faisal, Abdul Munir Mulkhan, Achmad Nurmandi, Hasse Jubba

supported by hard work, venture capital and sufficient knowledge in entrepreneurship and theological values carried as a Muslim about trying and working hard and trust capital in interacting with anyone, including with Papuans. These abilities are not only obtained from formal education but also obtained from a variety of life experiences to be able to innovate in sustaining life. Some of the capital and knowledge they get from the regional community they follow.

Migrants who are made up of many ethnic groups are unique. Javanese ethnicity is very well known for its tenacity. They pursue a lot of small economic sectors such as vegetable trading/business. Likewise, the BugisMakassar ethnic group is known for their hard work. They are very fanatical about helping their fellow regions. This ethnic is also good at using opportunities. Jan Boelaars (1986) states that ethnic Bugis and Makassarese are people who go everywhere, and they know to take advantage of local possibilities, then slowly build a good life. They start small, work hard, save money and thus can one day reach the top. In all things, they display a clear and genuine trading spirit. With great enthusiasm for developing trading businesses, these migrants gradually became the rulers of traditional markets in the Jayapura district, ranging from grocery, vegetables, fish, to medium-scale shop owners.

Political conditions that are not pro-migrant also give rise to creativity among them, especially opening new businesses that are small and medium scale. This was agreed by "WH", a Muslim migrant businessman, that:

My opinion related to the establishment of a Muslim migrant in Papua, ...that before the implementation of Special Autonomy, in 2001 what I see is that the attempt of lower and middle-class Muslims who start their business by opening small stalls or shops...23 The enactment of special autonomy seen as strengthened by the Papuan and
From Conflict to Assimilation: Strategies of Muslim Immigrants in Papua Special Autonomy Era marginalization of migrants. However, this marginalization has made migrants develop micro-businesses based on people's economy. In turn, Muslim migrants can control the economy because of their hard work and experience. Besides, they use their stock of knowledge they are able to mobilize their capital and negotiate the cultural values of a group or community. The result is that Muslim migrants control various economic sectors in the Jayapura district area. These economic sectors grow and open up various other economic sectors, both small and medium level.

In addition to the economic aspect, segmentation also appears in the political sphere. The tug-of-war between the indigenous Papuans and migrants in the public sphere in Jayapura district is currently very dynamic. At present, Jayapura's deputy regent is from Java. However, in certain contexts, migrants are in a subordinate position. Responding to this situation, migrants are involved in various activities and mobilize their potential to exist. The special autonomy policy indeed greatly influences the relations of migrants with indigenous Papuans. Conflict-style relationships are found in all levels of life, especially politics. This is closely related to the control of the political sector by indigenous Papuans, both executive and legislative.

The control of the political sector by indigenous Papuans not only influences the pattern of relations, but also the status of migrants and even impacts settlement or domicile. The migrants generally inhabit cities and coastal areas as a meeting place with locals. The history of the presence of migrants in the Jayapura district seems to be a little different if you look at the geographical location and the city center which is quite far from the beach. The majority of the migrant population, who were mobilized by the government through the transmigration program, were located in the Grime Nawa Valley (Nimbokrang and Yapsi

${ }^{23} \mathrm{WH}$, interview by Faisal, Jayapura, on November $15,2017$. 
Faisal, Abdul Munir Mulkhan, Achmad Nurmandi, Hasse Jubba

Districts). Therefore, the presence of migrants is also an inseparable part of the history of the birth of the Jayapura Regency. Counting several migrant leaders have occupied key positions in the bureaucracy of the Jayapura district government and the legislature (Jayapura Regency House of Representatives), even some prominent figures are considered to have an important role for the birth of Jayapura district.

As explained earlier, immigrant positions in the executive and legislative branches are vulnerable in line with the implementation of Law No. 21 of 2001. The spirit of "Papuanization" which is the main spirit of the law directly limits the presence of migrants, especially in occupying strategic positions, because they are considered to have the potential to violate the mandate of the constitution which only applies specifically in Papua. It is interesting to observe this phenomenon of Papuanization spirit, because in reality, political contestation that requires full public support, for example, the election of the regent/head of the region, is an accommodative phenomenon for migrants as a companion to native people because the potential of voters from a group of migrants greatly determines the choice of someone. Currently, the Jayapura regent, Giri Wijayanto (September 2017-September 2022) is a migrant from Java. A similar event had also occurred that migrant occupies the top of the regional leadership in Papua during the New Order era.

At present, migrants' relatively significant amount becomes sufficient capital to be taken into account in the involvement of the local political constellation. However, once again the number does not determine the entrants to be actively involved in politics. This is because the strong impetus comes from Papua's regulations or policies. In 2017, the total population of the Jayapura Regency was 228,558 people. Of this number, the migrant population was 78,495 people or $34.34 \%$. While the total population of Sentani City, Jayapura regency capital is 112,148 inhabitants, and the number of migrants reaches 43,481 inhabitants or $38 \%$. The actual number significant to involve
From Conflict to Assimilation: Strategies of Muslim Immigrants in Papua Special Autonomy Era

themselves in politics. However, the involvement of migrants in politics is more likely to be 'second line' in favor of indigenous Papuans in many ways. Political restrictions and their impact on Papuan life can at least be seen in the existence of a strong open space that demands the political rights of indigenous Papuans who have been controlled by the center, including the desire to demand independence. With these restrictions, the spirit of "Papuanization" which demands more roles in various fields and levels, but on the other hand political liberalization that occurred in 1998 which demanded the strong role of political parties along with the direct election system indirectly affected the access of migrants in political constellations in Papua.

The reality that there are restrictions on positions and greater portions for indigenous Papuans does not necessarily mean migrants do not participate in politics. They followed the situation by joining themselves with being administrators in various political parties, both nationalist and religious. In the 2014-2019 period, several Muslim immigrants were successfully elected as regional legislative members. For example, Ainur Rofiq, S. Pd (Java, PKS), Drs. H. Amin (Bugis, PKB) and $\mathrm{Hj}$. Sumirah (Bugis, NASDEM Party) and Abdurrahman Suleiman (Bugis, Golkar Party). Likewise, in the bureaucracy, the position of migrants in structural positions is also very limited due to the spirit of special autonomy. For migrants who should be able to occupy positions in the bureaucracy must stop temporarily while looking at opportunities and always available whenever needed at the position available. Position at the head of office/agency/office level in the regional government bureaucracy is majority occupied by indigenous Papuans. Migrants only occupy positions at a low level.

With the number of migrants, their votes are very calculated, especially when it comes to the interests of regional head elections. The position of migrants is very strategic because it can be a decisive winner of one of the candidates for the regional head. In the 2017 elections, for example, the couple Mathius 
Faisal, Abdul Munir Mulkhan, Achmad Nurmandi, Hasse Jubba

Awoitau-Giri Wijayantoro was a manifestation of the significance of the voices of immigrants. The couple consisted of indigenous Papuans (candidates for regent) and Javanese migrants (deputy candidates for regent) who eventually won the fight. The involvement of migrants for the couple's victory was recognized by several groups. A "CT" informant, Jayapura Regency Regional Government Civil Servants, said:

...here we are already like a big family that tied us together, building harmony among us and those influence our relationship, Jayapura, yes you say so, what ... we are here ... together, consist of a balanced population. ${ }^{24}$

The statement above not only shows the strong ties of regionalism among migrants but also explains the importance of collectivism. A large number of migrants helped determine the victory of one of the candidates for the regional head.

Those who are involved in political parties, for example, generally have different social backgrounds, both socio-cultural capital and economic capital. The cultural capital is elaborated when entering into political parties. Migrants who are part of the party, in general, are people who have the ability (financially) that can be used in building communication and relations with native Papuans. Also, the quality of migrant human resources is the key to success in entering political parties. These abilities they get from experience and education that have been passed through, some are obtained from formal education as a graduate in tertiary institutions, there is also experience in interacting for years in Papuan life such as being administrators of youth and community

\footnotetext{
${ }^{24} \mathrm{CT}$, interview by Faisal, Sentani, on October 2, 2017.

25 Some migrants who actively entered the various political parties both based on religion and nationalism and successfully entered the legislature. Like Ainur Rofiq, S.Pd.I (PKS Politician), Drs. H. Amin (PKB Politician) and Hj. Sumirah (NASDEM Party Politician) and Abdurrahman Suleiman (Golkar Party Politician). As for the executive level, is Giri Wijayantoro (Java, Deputy Regent of the 2017-2022 period). Similarly, in 2009, immigrants from different backgrounds tried to
}

From Conflict to Assimilation: Strategies of Muslim Immigrants in Papua Special Autonomy Era

organizations. So with carefulness in seeing the situation, it is possible to enter into politics. This capital also led several people (migrants) who were successfully elected to be representative at the Jayapura House of the legislature (DPRD)

Some figures from Muslim immigrants who succeeded in sitting in the legislature include Ainur Rofiq, S. Pd (Java, PKS), Drs. H. Amin (Bugis, PKB) and $\mathrm{Hj}$. Sumirah (Bugis, NASDEM Party) and Abdurrahman Suleiman (Bugis, Golkar Party). Likewise, in the 20092019 legislative elections, migrants can place their representatives in the legislature as a representation of their party and the constituents they represent, Drs. H. Nurdin Faisal (Makassar, GOLKAR), Bachtiar, SE (Bugis, PPP), Saharudin (Makassar, Labor Party), Ahmad Paito, S.Pd. I (Java, PKS) and Amir Hamzah (Java, PKB). Then in the executive office, the successful newcomer led the Democratic National Party politician, Giri Wijayantoro (Java, NASDEM) as the Jayapura regent's deputy from 2018-2023. They are elected through different party channels, meaning that it is not only for one political party. ${ }^{25}$

Their involvement in political parties which later made them elected cannot be separated from two conditions. First, demands for special autonomy for Papua that gave rise to new creativity for migrants. In the end, they did not remain silent and naturally followed the implementation of the special autonomy law. Second, internal support (immigrants) that allows direct involvement in politics (contestation) at the local level. The presence of migrants in the legislature not only

enter the party in the legislature in 2009 to 2019 immigrants may place representatives in the legislature as a representation of his party and the constituents they represent, Drs. H. Nurdin Faisal (GOLKAR politician), Bachtiar, SE (PPP politician), Saharudin (Labor Party politician), Ahmad Paito, S.Pd.I (PKS politician) and Amir Hamzah (political PKB). And also, migrants can deliver the National Democratic Party politician, Giri Wijayantoro as Jayapura district deputy regent for the 2018-2023 period to accompany the regent Mathius Awoitauw, SE., M.Sc in the government for five years. 
Faisal, Abdul Munir Mulkhan, Achmad Nurmandi, Hasse Jubba

complements the political dynamics in Jayapura Regency but also shows that there is a very well-established life orientation to continue to create shared spaces in developing Jayapura. Even migrants are no longer considered an exclusive group, even though there are quite strict restrictions. In line with the presence and involvement of immigrants in politics at the local level, Ainur Rofiq, a politician from one political party, stressed:

...because of the conditions in Papua that implement special autonomy, then we don't just accept it passively, at least with the opportunity available we can contribute and involve in its development. Even though the migrant can not be the top leader, at least we are in its circle in order that our present is taken into account. ${ }^{26}$

The condition of Papua's special autonomy, as described above, can at least be understood as a form of migrant contribution on the one hand, and political participation on the other. At the very least, this shows the desire of migrants to be part of the Jayapura district community despite objections.

Representation of migrants in the executive is reflected in the presence of deputy regents who come from migrants (Java). For researchers, this is a form of a successful negotiation for migrants in political pressures. On the other hand, the choice of some people who come from migrants to become legislative members cannot be separated from the conditions and demands for the importance of representation for migrants. They who try to remain present in the dynamics of local politics have severe challenges but are faced with a series of efforts including the active involvement of migrants in political parties. Events can be seen as pragmatism for migrants in politics. They realized that it was impossible to become the number one person in the Jayapura district. However, by being flexible they can still take political advantage by placing their representatives in second place in Jayapura. Thus, the representation of migrants
From Conflict to Assimilation: Strategies of Muslim Immigrants in Papua Special Autonomy Era is maintained even though it is always under the shadow of political pressure due to the implementation of special autonomy for Papua.

The migrants are unlikely to fight the force head-on. Not because indigenous Papuans are now stronger politically, but rather because there is a feeling of "self-awareness" as a migrant to adapt to the situation. The migrant still focuses on the survival strategy. If necessary, the migrant will only use a 'soft' way to establish their presence without physical and psychological pressure. As James. C. Scott said, like the analogy of the case of peasant laborers in Kedah Malaysia, how in the subtle resistance builds a survival strategy and struggles among the resistance..., (Scott, 1993: 169-170; Scott, 2000: 39-40). In this case, immigrants' "rebel" to the situation experienced not in a confrontational way but strategizing with continuous social dynamics. According to Abdul Munir Mulkhan sometimes a situation that might seem contradictory and theoretically negate each other's life in a community can inspire creativity that provides a new path, by merging values in synergy (Mulkhan, 2010: 291). This is the case for migrants in Papua, although they are not given much space in local politics, they continue to live with their existing routines and not close themselves to Papuans. Survive in adaptive ways to protect property rights that include their culture and identity.

Another thing that is no less important after the implementation of special autonomy in Papua is the strengthening of the role of regional organizations. This regional organization strengthening is carried out as a bargaining position and strategy to maintain the existence of migrants in Papua. Migrants need to communicate and share their bound through regional relations. These communities were originally formed to strengthen unity among migrants in one area. Regional communities that have been formed in Jayapura include ethnic elements of Sulawesi, Java-Madura, Sumatra, Maluku and Nusa Tenggara islands.

26 AR, interview by Faisal, Sentani, on July 18, 2017. 
Faisal, Abdul Munir Mulkhan, Achmad Nurmandi, Hasse Jubba

The relatively large elements of ethnic immigrant organizations are the South Sulawesi Family Harmony (KKSS) and the Java-Madura Family Association (HKJM). Regional associations are not only to strengthen the basis of membership but also as an adhesive from the pillars of the region so that this forum remains solid, especially in the face of fluctuating situations in Papua.

There are at least twelve pillars of South Sulawesi migrants who are members of the South Sulawesi Family Harmony (KKSS). The pillars are strengthening the base of BugisMakassar people in overseas. Likewise, it always coordinates the needs of its citizens with related parties, especially in the economic, political and socio-religious fields in Papua. The way they strengthen organizational ties is by conducting activities in the form of meetings such as recitation and social gathering. Also social activities in the form of visits the prisons in Sentani Barat and the sick or grieved citizens.

Meanwhile, the Javanese community organization has twenty-three pillars that are gathered from people who come from Java in general, East Java, West Java, and Central Java and the community that originated from Yogyakarta. The program includes regular meetings, religious gathering and visits the sick or grieving citizens.

Ethnic relations in Papua need to be encouraged in the framework of minimizing potential tensions that lead to ethnic conflict. Ethnic solidity, both shown by migrants and residents in Papua, is feared to accumulate into confrontations between migrants and nonmigrants. Even the phenomenon of strengthening ethnic solidity thus obtains new channels which in the future will further strengthen ethnic politics. Thus, geographical mobility, which is nothing but the mobility of the population from diverse cultural environments - in the context of a repressive political structure - proven to be able to harden "exclusivity" and "intolerance" between migrants and residents from different cultural environments. For this reason, the assimilation process between residents and migrants needs
From Conflict to Assimilation: Strategies of Muslim Immigrants in Papua Special Autonomy Era to be echoed and pursued, especially in the context of Papua.

\section{CONCLUSION}

Papua's special autonomy (otsus) is a regulation that gives Papuans full rights to redefine their identity, including economic and political identity. In this context, Papuans have full rights in the economic and political space. This fact is certainly a threat to migrant citizens, who are mostly Muslim, who previously dominated the economic and political fields. The presence of migrants, who are predominantly Muslim, has made an important contribution to the development of Papua. Control of the economic sector to date can be seen as an effort to prove the contribution of the challenger to the community, although often also considered a form of 'mastery' of Papua.

Although the mastery of the economic sector is going well, it does not occur in the political sector. Special Autonomy which does provide a great opportunity for Papuans to be actively involved in the management of Papua marginalizes migrants. Limited access, on the one hand, makes immigrants, especially Muslims, marginalized, but on the other hand, it becomes the trigger of success in the current economic sector. The relationship between Muslim migrants and residents is very dynamic which is also interspersed with tension and even conflict. Success in the economic sector provides a negotiating space for migrants to survive with all the risks.

Muslim migrants feel the need to formulate a survival strategy from the dominance of indigenous Papuans over economic and political space. Muslim migrants must adapt or assimilate to the realities of community life in Papua. So that the potential tension that can lead to open conflict can be avoided. However, in addition to Papua, in many areas, there are fears of the dominance of migrant communities that will threaten the existence of local communities. Therefore, ethnic and interreligious relations need to be constantly reunited, so that the economic and political spaces become relatively more fragmented. 
Faisal, Abdul Munir Mulkhan, Achmad Nurmandi, Hasse Jubba
From Conflict to Assimilation: Strategies of Muslim Immigrants in Papua Special Autonomy Era

\section{BIBLOGRAPHY}

Abdullah, Irwan. Konstruksi Dan Reproduksi Kebudayaan. Yogyakarta: Pustaka Pelajar, 2006.

Akhmad, Pujo Semedi. "Amber Dan Komin: Studi Perubahan Ekonomi Di Papua." Sosiohumanika 16B, no. 2 (2003): 229--245.

Allen, Chris. "Contemporary Islamophobia Before 9/11: A Brief History in Islamophobia and Anti-Muslim Hatred: Cause \& Remedie." Arches Quarterly 4, no. 7 (2010): 14-22.

- Islamophobia. England: Ashgate Publishing Limited, 2010.

Asyhari-Afwan, Budi. Mutiara Terpendam Papua Potensi Kearifan Lokal Untuk Perdamaian Di Tanah Papua. Yogyakarta: CRCS UGM, 2015.

Badan Pusat Statistik Provinsi Papua. Produk Domestik Regional Bruto Provinsi Papua Tahun 2015. Jayapura: Badan Pusat Statistik Provinsi Papua, 2015.

Drouhot, Lucas G, and Victor Nee. "Assimilation and the Second Generation in Europe and America: Blending and Segregating Social Dynamics between Immigrants and Natives." Annual Review of Sociology 45 (2019).

Eidemiller, K Yu, E A Samylovskaya, R E A Kudryavtseva, and A E Alakshin. "Social and Islamic Diffusion in the Nordic Countries with the Example of Sweden by Year 2050." In IOP Conference Series: Earth and Environmental Science, 302:12071. IOP Publishing, 2019.

Fajar, Muhammad. "Identifikasi Sektor Potensial Provinsi Papua." Bandung, 2017.

Gusnelly. "Migrasi, Kewarganegaraan, Dan Partisipasi Ipendatang: Studi Kasus Pendatang Turki Di Belanda." Jurnal Kajian Wilayah 1, no. 1 (2010): 59-78.

Handayani, Sri Ana. Transmigrasi Di Indonesia Dalam Perspektif Sejarah. Jember: Universitas Jember, 1994.

Hidayat, Zinggara. "Dampak Teknologi Digital Terhadap Perubahan Konsumsi Media Masyarakat." KOMUNIKOLOGI: Jurnal Ilmiah Ilmu Komunikasi 13, no. 2 (2016): 59-77.
Ismail, Rudi Hartono, and Rianik Thomas. "Building the Civilization in the Perspectives of Islam in Jayawijaya Regency, Papua, Indonesia: The Development of Islam in the Aspect of Human Resources." HONAI 1, no. 1 (2018): 61-72.

Izzah, Atiyatul. "Jaringan Sosial Dan Variasi Pekerjaan Para Migran Di Kota Samarinda." MASYARAKAT, Jurnal Sosiologii 16, no. 2 (2011): 157-80.

Mantra, I. B. Pengantar Studi Demografi. Yogyakarta: Nur Cahaya, 1985.

Milles, and Huberman. Analisis Data Kualitatif. Jakarta: Universitas Indonesia Press, 1992.

Pecoud, Antoine. Weltoffenheit Schafftjobs: Turkish Entrepreneurship and Multiculturalism in Berlin. Oxford, UK: University of Oxford, 2000.

Raja, Rahat. "Muslims in Europe A Shared Citizenship Transcending the Imposition of Cultural Homogeneity." Policy Perspectives, 2012, 109-41.

Saprillah. "Migrasi Kaum Muslim Ke Sorong Papua Barat." Al-Qalam 17, no. 2 (2011): 251-61.

Setiawan, Bayu. "Program Transmigrasi: Upaya Mengatasi Permasalahan Kependudukan Dan Meningkatkan Kesejahteraan Masyarakat.” In Pertumbuhan Penduduk Dan Kesejahteraan, edited by Mita Noveria. Jakarta: LIPI Pres, 2011.

Setiawan, Nugraha. Transmigrasi Di Indonesia: Sejarah Dan Perkembangannya. Yogyakarta: Program Studi Kependudukan, Program Pascasarjana UGM, 1994.

Snodgrass, Donald R. Successful Economic Development in a Multi-Ethnic Society: The Malaysian Case. Cambridge: Harvard Institute for International Development, Harvard University, 1995.

Suryawan, I Ngurah. "Komin Tipu Komin: Elit Lokal Dalam Dinamika Otonomi Khusus Dan Pemekaran Daerah Di Papua." Jurnal Ilmu Sosial Dan Ilmu Politik 15, no. 2 (2011): 140-53.

Trust, Runnymede. Islamophobia: A Challenge 
Faisal, Abdul Munir Mulkhan, Achmad Nurmandi, Hasse Jubba
From Conflict to Assimilation: Strategies of Muslim Immigrants in Papua Special Autonomy Era for Us All. London: Runnymede Trust, 1997.

Upton, Stuart. "The Impact of Migration on the People of Papua, Indonesia: A Historical Demographic Analysis." Department of History and Philosophy, UNSW, 2009.

Wally, John Manangsang. Dunia Dalam Genggaman Papua Sebuah Fenomena Geopolitik Global. Jayapura: Yayasan Gratia Papua Jayapura, 2018.

Wanggai, Toni Victor M. Rekonstruksi Sejarah Umat Islam Di Tanah Papua. Jakarta: Badan Litbang dan Diklat Departemen Agama, 2009.

Wekke, Ismail Suardi. "Migrasi Bugis Dan Madura Di Selatan Papua Barat: Perjumpaan Etnis Dan Agama Di Minoritas Muslim." Jurnal Intelektualita: Keislaman, Sosial
Dan Sains 6, no. 2 (2017): 163--180.

Yuniarti, Fandri, ed. Ekspedisi Tanah Papua: Laporan Jurnalistik Kompas Terasing Di Pulau Sendiri. Jakarta: Kompas, 2008.

\section{INTERVIEW}

A, interview by Faisal. Jayapura. September 30, 2017.

S, interview by Faisal. Sentani. September 30, 2017.

WH, interview by Faisal. Jayapura. November $15,2017$.

CT, interview by Faisal. Sentani. October 2, 2017.

AR, interview by Faisal. Sentani. July 18, 2017. 